\title{
Inhibition of melanoma tumor growth by a pharmacological inhibitor of MetAP-2, PPI-2458
}

\author{
GERHARD HANNIG $^{1 *}$, DOUGLAS D. LAZARUS ${ }^{1,2^{*}}$, SYLVIE G. BERNIER ${ }^{1}$, RUSSELL M. KARP $^{1}$, \\ JEANINE LORUSSO $^{1}$, DANIEL QIU ${ }^{1}$, MATTHEW T. LABENSKI ${ }^{1}$, JIM D. WAKEFIELD ${ }^{1,3}$, \\ CHARLES D. THOMPSON ${ }^{1,4}$ and WILLIAM F. WESTLIN ${ }^{1}$ \\ ${ }^{1}$ PRAECIS Pharmaceuticals, Incorporated, 830 Winter Street, Waltham, MA 02451; ${ }^{2}$ PharmaMar USA, \\ 320 Putnam Avenue, Cambridge, MA 02139; ${ }^{3}$ Microbia, 320 Bent Street, Cambridge, MA 02141; \\ ${ }^{4}$ MERCK \& Co., Incorporated, 770 Sumneytown Pike, West Point, PA 19486, USA
}

Received November 4, 2005; Accepted December 12, 2005

\begin{abstract}
Over the past few decades, melanoma has shown the fastest growing incidence rate of all cancers. This malignancy is clinically defined by its potential to rapidly metastasize, and advanced metastatic melanomas are highly resistant to existing therapeutic regimens. Here, we report that PPI-2458, a novel, orally active agent of the fumagillin class of irreversible methionine aminopeptidase-2 (MetAP-2) inhibitors, potently inhibited the proliferation of B16F10 melanoma cells in vitro, with a growth inhibitory concentration $50 \%\left(\mathrm{GI}_{50}\right)$ of $0.2 \mathrm{nM}$. B16F10 growth inhibition was correlated with the inhibition of MetAP-2 enzyme, in a dose-dependent fashion, as determined by a pharmacodynamic assay, which measures the amount of uninhibited MetAP-2 following PPI-2458 treatment. Prolonged exposure of B16F10 cells to PPI-2458 at concentrations of up to $1 \mu \mathrm{M}, 5,000$-fold above the $\mathrm{GI}_{50}$, did not alter their sensitivity to PPI-2458 growth inhibition and no drug resistance was observed. Moreover, prolonged exposure to this agent induced melanogenesis, concomitant with the elevated expression of the melanocyte-specific enzymes tyrosinase and tyrosinaserelated proteins (TRP) 1 and 2, a morphological feature associated with differentiated melanocytes. PPI-2458, when administered orally (p.o.), significantly inhibited B16F10 tumor growth in mice in a dose-dependent fashion, with a maximum inhibition of $62 \%$ at $100 \mathrm{mg} / \mathrm{kg}$. This growth inhibition was directly correlated to the amount of irreversibly inhibited MetAP-2 (80\% at $100 \mathrm{mg} / \mathrm{kg}$ PPI-2458) in tumor tissue. These data demonstrate that PPI-2458 has potent antiproliferative activity against $\mathrm{B} 16 \mathrm{~F} 10$ cells in vitro and in vivo,
\end{abstract}

Correspondence to: Dr Gerhard Hannig, PRAECIS Pharmaceuticals, Incorporated, Department of Preclinical Research, 830 Winter Street, Waltham, MA 02451, USA

E-mail: gerhard.hannig@praecis.com

${ }^{*}$ Contributed equally

Key words: enzyme inhibition, melanogenesis, melanoma, MetAP-2, PPI-2458 and that both activities are directly correlated with levels of MetAP-2 enzyme inhibition. This antiproliferative activity, coupled with additional observations from studies in vitro (absence of detectable resistance to PPI-2458 and induction of morphological features consistent with differentiated melanocytes), provides a rationale for assessing the therapeutic potential of PPI-2458 in the treatment of melanoma.

\section{Introduction}

Melanomas develop after the malignant transformation of melanocytes, specialized melanin producing cells which reside in the epidermal basement membrane of the skin. The incidence rate of this cancer has increased 15 -fold over the past four decades, far more rapidly than that of any other cancer (1). In 2005, an estimated 55,000 Americans will be affected by this disease, ranking melanoma as the sixth most common cancer in the United States (2).

Treatment options for advanced, metastatic melanoma are limited and the clinical prognosis for these patients is poor. The only chemotherapeutic drug approved by the FDA as single agent therapy for this disease, dacarbazine (DTIC), has yielded low objective response rates with no apparent survival benefit $(3,4)$. DTIC combination therapies with conventional cytotoxic drugs, such as CVD (cisplatin, vinblastine, DTIC) or BOLD (bleomycin, vincristine, lomustine, DTIC) failed to demonstrate superiority over DTIC single agent therapy in phase III clinical trials (3). Immunological approaches for the treatment of advanced metastatic melanoma have yielded only two FDA-approved agents over the past three decades, high-dose bolus IL-2 and IFN $\alpha-2 b(5,6)$. These agents have shown clinical benefit in $\leq 10 \%$ of patients, but are associated with severe toxicities $(5,6)$. Furthermore, phase III clinical studies evaluating combination regimens of either IL-2 or IFN $\alpha-2 b$ with conventional cytotoxic drugs (biochemotherapy) have not shown a statistically significant increase in overall survival rates (7). Other immunological approaches have focused on the development of autologous and allogeneic vaccines. Specifically, several melanogenic proteins, such as tyrosinase, TRP-1 and TRP-2, which are lineage-specific markers of differentiated melanocytes, have been demon- 
strated to function as targets of humoral and cellular immune responses, suggesting their potential for therapeutic applications (8-12). Despite this broad array of melanoma-targeting approaches, marked resistance of these tumors to existing therapies remains a hallmark of this disease. Therefore, innovative therapies, such as mechanism-based drugs targeting yet unexplored pathways in melanoma are desperately needed.

PPI-2458 is a novel, orally active analog of the fumagillin class of irreversible inhibitors of MetAP-2. This enzyme was originally identified as the molecular target of this class of molecules by biochemical approaches $(13,14)$, and the molecular nature of this interaction was subsequently confirmed by the crystal structure of human MetAP-2 complexed with fumagillin (15). More recently, functional studies have provided additional experimental evidence that MetAP-2 is the molecular target and is a critical regulator of mammalian cell growth (16).

In this report, we show that PPI-2458 potently inhibited B16F10 melanoma cell growth in vitro and the growth of B16F10 melanoma in mice. We demonstrate that PPI-2458 dependent growth inhibition was correlated with the inhibition of MetAP-2 enzyme in vitro and in vivo. Moreover, prolonged exposure of $\mathrm{B} 16 \mathrm{~F} 10$ cells to $\mathrm{PPI}-2458$ concentrations significantly above the $\mathrm{GI}_{50}$ did not generate drug resistance, and at the same time induced melanogenesis, which is functionally associated with the differentiated phenotype of melanocytes. These data provide a rationale for assessing the therapeutic potential of PPI-2458 as a novel, molecularly targeted therapy for the treatment of melanoma.

\section{Materials and methods}

Reagents. PPI-2458 and a biotinylated analog of PPI-2458 were synthesized at PRAECIS Pharmaceuticals. For in vitro assays, PPI-2458 was dissolved in ethanol $(10 \mathrm{mM})$. Dacarbazine (DTIC), 5-Fluorouracil (5-FU), and melanin were obtained from Sigma. 2-Hydroxyl-beta-cyclodextrin (HPCD) was purchased from Cargill Incorporated. [ $\left.{ }^{3} \mathrm{H}\right]$-thymidine was obtained from Amersham.

Proliferation assays. B16F10 murine melanoma cells were obtained from the American Type Culture Collection (ATCC). The cells were cultured in DMEM supplemented with fetal bovine serum $(10 \% \mathrm{v} / \mathrm{v})$, penicillin-streptomycin (100 units/ml and $100 \mu \mathrm{g} / \mathrm{ml}$, respectively) and L-glutamine ( $2 \mathrm{mM})$. For proliferation assays, $1 \times 10^{3}$ cells $\left(5 \times 10^{3}\right.$ cells $\left./ \mathrm{ml}\right)$ were seeded in 96-well plates (in triplicate) and incubated with varying concentrations of drug, as indicated. After 3 days, $1 \mu \mathrm{Ci} /$ well $\left[{ }^{3} \mathrm{H}\right]$-thymidine was added for the final $24 \mathrm{~h}$ of incubation. Cell proliferation was determined by the amount of incorporated $\left[{ }^{3} \mathrm{H}\right]$-thymidine, by using liquid scintillation counting.

To generate PPI-2458-resistant B16F10 cells, the cells were incubated for 6-8 weeks with PPI-2458 at concentrations of either 0.1 or $1 \mu \mathrm{M}$. Seventy-five single clones were selected from each concentration, analyzed in proliferation assays and compared to a B16F10 cell clone that had not been previously exposed to PPI-2458, as described above.

Western blot analysis. After treatment, cells were washed once with phosphate-buffered saline (PBS), harvested in buffer
A [50 mM Tris- $\mathrm{HCl}, \mathrm{pH} 7.4,1 \%$ Nonidet P-40, $0.25 \%$ sodium deoxycholate, $150 \mathrm{mM} \mathrm{NaCl}, 1 \mathrm{mM}$ EDTA, $2 \mathrm{mM} \mathrm{Na}_{3} \mathrm{VO}_{4}$, $1 \mathrm{mM} \mathrm{NaF}$, and complete protease cocktail inhibitor (Roche)], solubilized for $30 \mathrm{~min}$ at $4^{\circ} \mathrm{C}$, and centrifuged at $14,000 \mathrm{x} \mathrm{g}$ for $15 \mathrm{~min}$. For tissue homogenization and cell lysis, $\sim 0.2 \mathrm{~g}$ of tumor tissue was first homogenized in ice-cold PBS containing complete protease cocktail inhibitor using a tissue grinder (Kendall) and then solubilized as described above by adding $0.1 \mathrm{Vol}$ of buffer A (10-fold). For Western blot analysis, $30 \mu \mathrm{g}$ of cellular protein was used. For protein detection in cell lysates, we used the following antibodies: MetAP-1 polyclonal antibody (Mediomics), MetAP-2 polyclonal antibody CM33 (Zymed), B-actin monoclonal antibody AC-15 (Sigma), and p21 CIP/WAF monoclonal antibody F5, tyrosinase polyclonal antibody C-19, and TRP-1 and TRP-2 polyclonal antibodies G-17 and G-15, respectively, were from Santa Cruz.

MetAP-2 assay. The MetAP-2 assay was performed as previously described $(16,17)$. Briefly, $10-20 \mu \mathrm{g}$ of cellular or tumor-derived protein was incubated with a biotinylated analog of PPI-2458. This analog covalently binds to the catalytic site of MetAP-2 which enables determination of the amount of total cellular MetAP-2, or the amount of uninhibited MetAP-2 which had not been derivatized by prior treatment with PPI-2458. The biotinylated MetAP-2-inhibitor complex was captured on a plate with immobilized streptavidin (Pierce), and detected with the MetAP-2 antibody CM33 $(0.5 \mu \mathrm{g} / \mathrm{ml})$, followed by horseradish peroxidase-conjugated goat anti-rabbit IgG secondary antibody. The amount of uninhibited MetAP-2 was determined by measuring the absorption at $450 \mathrm{~nm}$ using a Labsystems Multiskan plate spectrophotometer. Human recombinant MetAP-2 (Mediomics), prebound to the biotinylated PPI-2458 analog, was used to generate the standard curve.

Melanin secretion. To measure the amount of secreted melanin, $1 \times 10^{5} \mathrm{~B} 16 \mathrm{~F} 10$ cells $\left(5 \times 10^{4}\right.$ cells $\left./ \mathrm{ml}\right)$ from previously selected clones following exposure to either $0.1 \mu \mathrm{M}$ (clones 100 and 101) or $1 \mu \mathrm{M}$ (clone 129) of PPI-2458 were seeded in 6-well plates (triplicates), and PPI-2458 was added at different concentrations to the growth medium. After 7 days, the amount of secreted melanin was determined by measuring the optical density (OD) at $492 \mathrm{~nm}$, derived from a standard curve prepared with synthetic melanin dissolved in growth medium (18). To determine whether PPI-2458-induced melanogenesis was reversible, B16F10 cells from clones 100, 101, and 129 were seeded at $1 \times 10^{5}$ cells $\left(5 \times 10^{4}\right.$ cells $\left./ \mathrm{ml}\right)$ in 6 -well plates (triplicates), and incubated in either drug-free medium, or PPI-2458 containing medium $(0.1 \mu \mathrm{M}$ of PPI-2458 for clones 100 and 101 , or $1 \mu \mathrm{M}$ of PPI-2458 for clone 129) for 7 days. The cells were split and seeded at $5 \times 10^{4}$ cells/well (triplicates) in fresh medium containing either no drug or PPI-2458 for another 7-day period. The growth medium was collected and the amount of melanin measured as described above.

Mouse B16F10 syngeneic tumor model. Male C57BL/6 mice (7 weeks of age) were purchased from Charles River Laboratories (Wilmington, MA) and randomized into groups of 10 animals each. $1 \times 10^{6} \mathrm{~B} 16 \mathrm{~F} 10$ cells $\left(1 \times 10^{7} / \mathrm{ml}\right)$ in PBS were injected subcutaneously (s.c.) above the right hind leg. Tumor 
growth was measured every 2-3 days using a CD-8" CS digital caliper (Mitutoyo Corp., Japan), and tumor volumes were calculated following the equation: volume $=$ (width $\mathrm{x}$ width) (length)/2. 5-FU was formulated at $10 \mathrm{mg} / \mathrm{ml}$ in PBS and administered intraperitoneally (i.p.) at $50 \mathrm{mg} / \mathrm{kg} 3 \mathrm{x} /$ week. PPI-2458 was formulated in $11 \% \mathrm{HPCD}$, and mice were dosed orally with $1,3,30$ or $100 \mathrm{mg} / \mathrm{kg}$ or vehicle on alternate days (QOD), or received PPI-2458 orally at $100 \mathrm{mg} / \mathrm{kg}$ every 3 days (Q3D) or every 4 days (Q4D) to determine schedule dependency of observed effects. Treatment with 5-FU, PPI-2458 or vehicle started at day 6 post tumor implantation and concluded at day 20. Mice were sacrificed 21 days post tumor implantation, tumors were removed, weighed, frozen in liquid nitrogen and stored at $-80^{\circ} \mathrm{C}$. All animal studies were approved by the PRAECIS Institutional Animal Care and Use Committee.

\section{Results}

PPI-2458 is a potent inhibitor of B16F10 cell proliferation. PPI-2458 is a novel, structural analog of the fumagillin class of irreversible MetAP-2 inhibitors, which has previously been demonstrated to potently inhibit the proliferation of human umbilical vein endothelial cells (HUVEC) and human fibroblast-like synoviocytes from rheumatoid arthritis patients (HFLS-RA) in vitro $\left(\mathrm{GI}_{50}: 0.2 \mathrm{nM}\right.$ and $0.04 \mathrm{nM}$, respectively) $(16,17)$. Furthermore, this growth inhibition, by a mechanism of cell cytostasis, directly correlated with the depletion of enzymatically active MetAP-2 in these cells, in a dosedependent manner $(16,17,19)$. We examined the antiproliferative activity of PPI-2458 on murine B16F10 melanoma cells in vitro and observed potent growth inhibition of these cells with a $\mathrm{GI}_{50}$ of $0.2 \mathrm{nM}$, and a maximum growth inhibition of $\sim 80 \%$ at concentrations of $\geq 10 \mathrm{nM}$ (Fig. 1A). Moreover, PPI-2458-induced growth inhibition was completely reversible after removal of this agent, and no cytotoxicity was detected at concentrations of up to $10 \mu \mathrm{M}$ (data not shown), consistent with previous observations in other cell types $(16,17)$. Dacarbazine (DTIC), the only FDA-approved drug for single agent therapy in advanced metastatic melanoma, had no growth inhibitory activity on $\mathrm{B} 16 \mathrm{~F} 10$ cells, at concentrations of up to $10 \mu \mathrm{M}$ (data not shown).

MetAP-2 enzyme inhibition correlates with B16F10 growth inhibition. To determine whether the PPI-2458 induced growth inhibition of B16F10 cells correlated with MetAP-2 enzyme inhibition, we measured the amount of free MetAP-2 (not covalently bound by PPI-2458) in these cells after treatment with PPI-2458, using the pharmacodynamic MetAP-2 assay described above. B16F10 cell growth inhibition closely correlated to the amount of inhibited MetAP-2, up to drug concentrations of $\geq 10 \mathrm{nM}$, at which both maximal growth inhibition (80\%) and enzyme inhibition (100\%) were obtained (Fig. 1A). These results are consistent with previous findings of cell type-specific sensitivity to PPI-2458 induced growth inhibition $(16,17)$.

Regulation of MetAP-2, MetAP-1 and p21 CIP/WAF protein expression in B16F10 cells after treatment with PPI-2458. We performed Western blot analysis to determine the levels

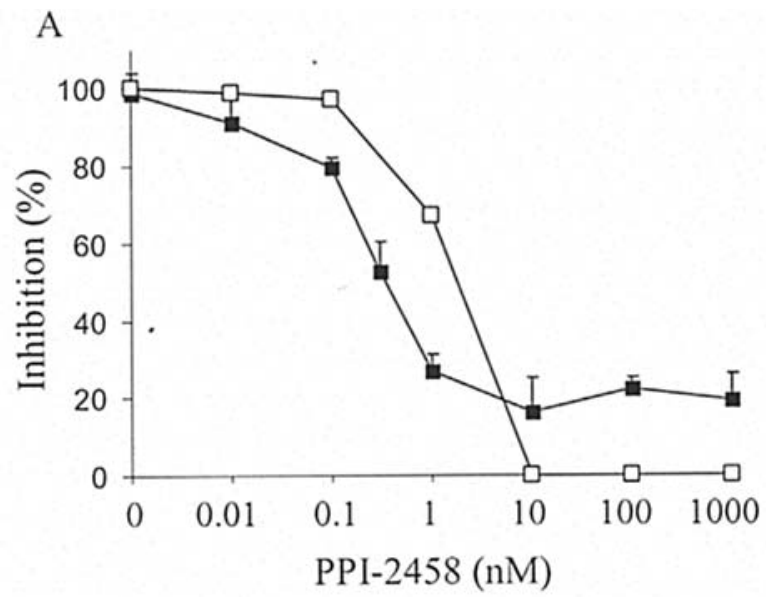

B

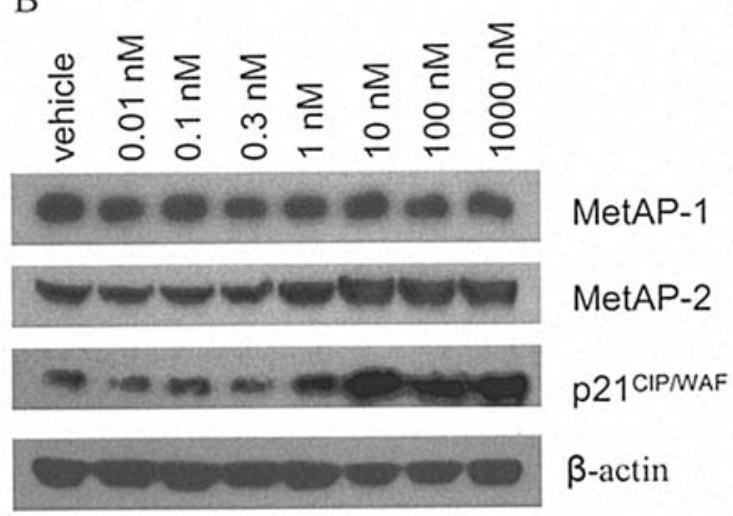

Figure 1. PPI-2458-mediated growth inhibition in B16F10 cells correlates with MetAP-2 enzyme inhibition (A). B16F10 cells $\left(1 \times 10^{3}\right.$ cells) were incubated with increasing concentrations of PPI-2458 $\left(10^{-11}-10^{-6} \mathrm{M}\right)(\boldsymbol{\square})$ for 4 days. For the final $24 \mathrm{~h}, 1 \mu \mathrm{Ci} /$ well of $\left[{ }^{3} \mathrm{H}\right]$-thymidine was added and cell proliferation was determined by $\left[{ }^{3} \mathrm{H}\right]$-thymidine incorporation. The results represent the mean and standard deviation of triplicate wells and are representative of at least 3 independent experiments. The MetAP-2 assay was performed with lysates from B16F10 cells which had been cultured on parallel plates, without the addition of $\left[{ }^{3} \mathrm{H}\right]$-thymidine. The amount of uninhibited MetAP-2 $(\square)$ was measured as described in Materials and methods. In B16F10 cells not treated with PPI-2458, the amount of uninhibited MetAP-2 $(=100 \%)$ was $60.5 \pm 4.8 \mathrm{ng} / \mathrm{mg}$ of cellular protein. (B) Regulation of MetAP-1, MetAP-2, p21 CIP/WAF, and B-actin expression in B16F10 cells after treatment with PPI-2458. Western blot analysis (30 $\mu \mathrm{g}$ of cellular protein) was performed on the same cell lysates used for the MetAP-2 assay as described in Materials and methods.

of MetAP-2 in PPI-2458 growth-inhibited B16F10 cells and found that MetAP-2 protein levels were significantly increased after prolonged exposure ( $96 \mathrm{~h}$ ) to this agent (Fig. 1B). This observation is consistent with previously reported data that showed an increase in cellular MetAP-2 in endothelial cells and HFLS-RA after exposure to fumagillin or PPI-2458 $(16,17)$. Similarly to MetAP-2, MetAP-1 is a critical regulator of mammalian cell growth (16). When mammalian cells were made functionally deficient in both MetAPs, their ability to proliferate was almost completely inhibited (16). In growth-inhibited B16F10 cells, MetAP-1 protein was expressed constitutively at high levels, suggesting that the expression of this protein was not affected after exposure of these cells to PPI-2458 (Fig. 1B). In HUVEC, the block in late $\mathrm{G}_{1}$ cell cycle progression induced by fumagillin class MetAP-2 inhibitors is postulated to be triggered by activation of the 


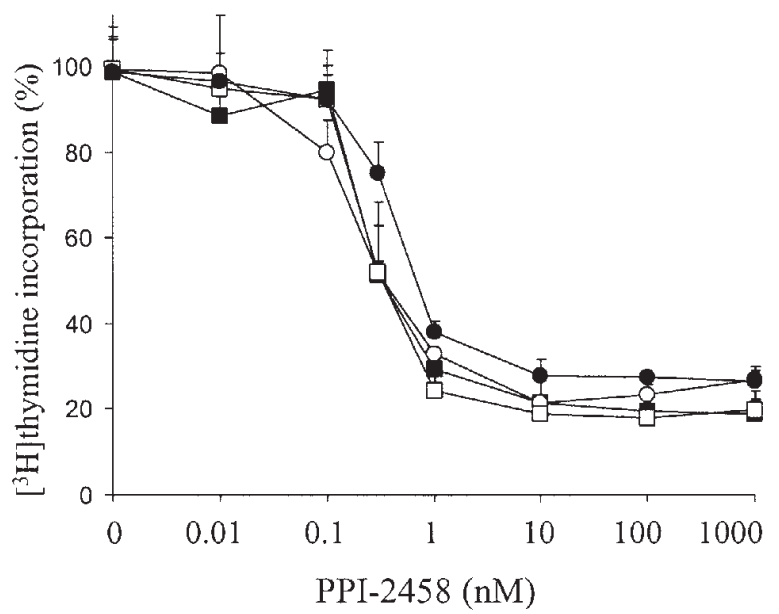

Figure 2. B16F10 cells do not develop resistance to PPI-2458 growth inhibition (data shown for 4 representative clones). B16F10 cells were grown for 6-8 weeks in the presence of either 0.1 or $1 \mu \mathrm{M}$ PPI-2458. B16F10 cells on parallel plates were grown in the absence of PPI-2458 (control). Single clones were isolated from each experimental condition $[0.1 \mu \mathrm{M}$ PPI-2458: clones $100(\circ), 101(\square) ; 1 \mu \mathrm{M}$ PPI-2458: clone $129(\bullet)$; no PPI-2458: clone $G(\boldsymbol{\omega})]$ and cells were analyzed for their resistance to PPI-2458 growth inhibition. $1 \times 10^{3}$ cells/well were seeded into 96-well plates and incubated with increasing concentrations $\left(10^{-11}-10^{-6} \mathrm{M}\right)$ of PPI-2458 for 4 days. For the final $24 \mathrm{~h}, 1 \mu \mathrm{Ci} /$ well of $\left[{ }^{3} \mathrm{H}\right]$-thymidine was added and cell proliferation was determined by the amount of incorporated $\left[{ }^{3} \mathrm{H}\right]$-thymidine. The results represent the mean and standard deviation of triplicate wells and are representative of at least 3 independent experiments.

p53 pathway, accompanied by intracellular accumulation of the cell cycle inhibitor protein p21 $1^{\mathrm{CIP} / \mathrm{WAF}}(20,21)$. Although studies of genomic alterations in several growth regulatory genes in B16F10 cells have failed to detect mutations in the p53 tumor suppressor gene, p53 protein expression in these cells was relatively low due to the inactivation of the p19ARF tumor suppressor gene, which blocks the MDM-2 mediated degradation of p53 (22). Since this finding suggested that the $\mathrm{p} 53 / \mathrm{p} 21^{\mathrm{CIP} / \mathrm{WAF}}$ pathway could still be functional in B16F10 cells, we examined the level of $\mathrm{p} 21^{\mathrm{CIP} / \mathrm{WAF}}$ protein after treatment with PPI-2458. Significantly elevated levels of p $21^{\mathrm{CIP} / \mathrm{WAF}}$ protein were detected at concentrations of $\geq 10 \mathrm{nM}$ PPI-2458, consistent with the concentration range of this agent where maximal growth inhibition was observed (Fig. 1B). These results suggest a potential role for $\mathrm{p} 21^{\mathrm{CIP} / \mathrm{WAF}}$ in the regulation of B16F10 cell growth.

B16F10 cells do not develop resistance to PPI-2458 growth inhibition. Advanced, metastatic melanomas are highly resistant to currently available treatment regimens. We examined the ability of B16F10 cells to develop resistance against PPI-2458 after prolonged exposure. B16F10 cells were incubated for 6-8 weeks with PPI-2458 at concentrations of either 0.1 or $1 \mu \mathrm{M}$, previously determined to exceed the $\mathrm{GI}_{50}$ of these cells by 500 -fold to 5,000 -fold, respectively. Under those conditions, B16F10 cells continued to proliferate, albeit slowly, and the analysis of 150 single clones tested in proliferation assays for resistance to PPI-2458 confirmed that all remained sensitive to PPI-2458 growth inhibition (Fig. 2). Moreover, we detected no quantitative differences in the level of growth inhibition when compared to B16F10 cells which had not been previously
A
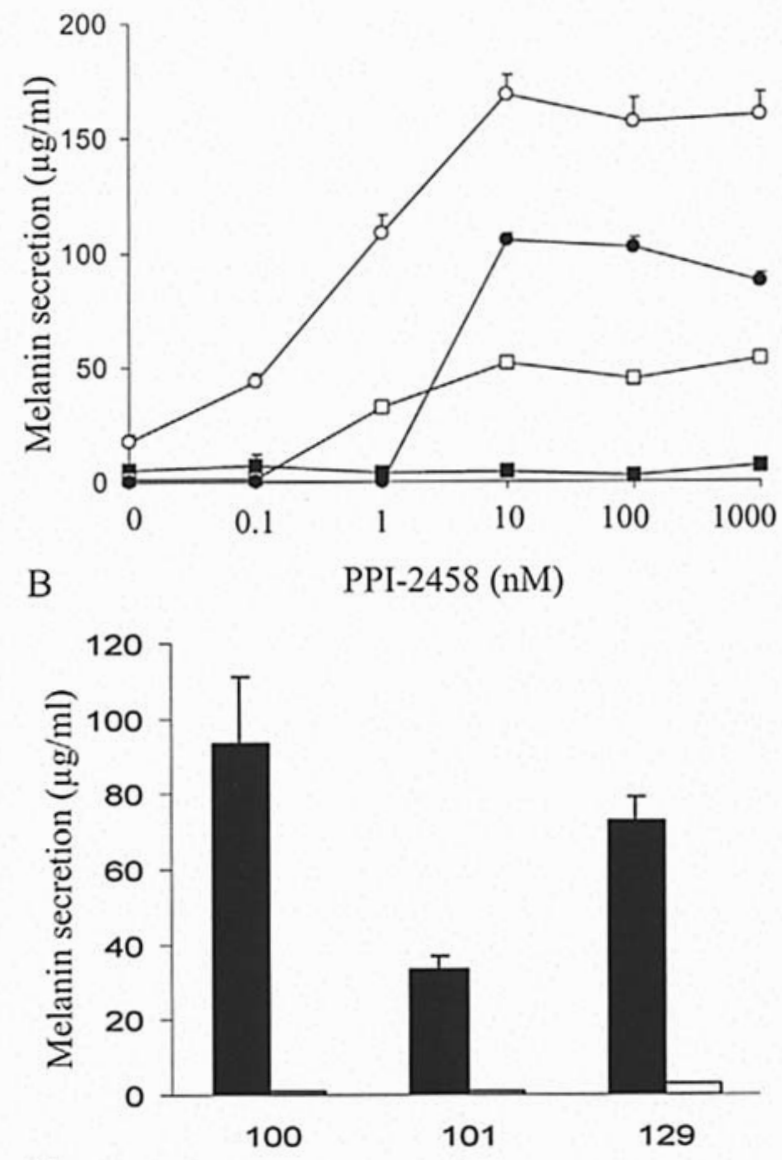

C
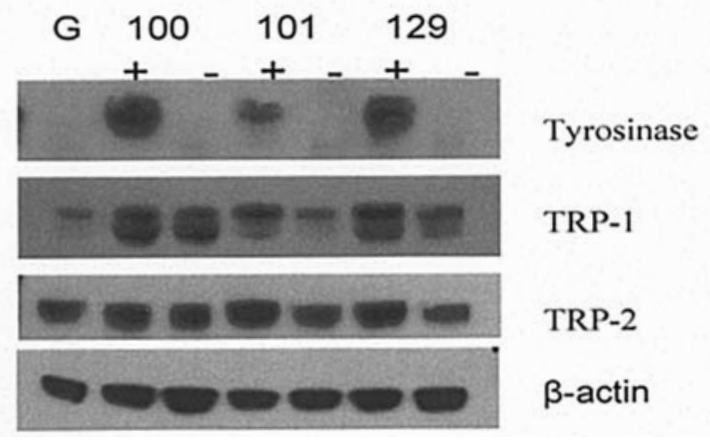

Figure 3. Prolonged exposure to PPI-2458 induces melanin secretion (A and $\mathrm{B})$, concomitant with elevated protein expression of tyrosinase, TRP-1 and TRP-2 in B16F10 cells (C). (A) B16F10 cells were grown for 6-8 weeks in presence of either 0.1 or $1 \mu \mathrm{M}$ PPI-2458. B16F10 cells on parallel plates were grown in the absence of PPI-2458 (control). Single clones were isolated from each experimental condition [0.1 $\mu \mathrm{M}$ PPI-2458: clones $100(0), 101$ $(\square)$; $1 \mu \mathrm{M}$ PPI-2458: clone 129 (•); no PPI-2458: clone $\mathrm{G}(\boldsymbol{\square})]$ and analyzed for melanin secretion into the growth medium. $1 \times 10^{5}$ cells/well were seeded into 6-well plates and incubated with increasing concentrations $\left(10^{-10}-10^{-6} \mathrm{M}\right)$ of PPI-2458, and the amount of secreted melanin was determined after 7 days by measuring the $\mathrm{OD}_{492 \mathrm{~nm}}$. (B) PPI-2458-dependent melanogenesis is reversible. B16F10 cells $\left(1 \times 10^{5}\right.$ cells/well) in 6-well plates were grown in the presence of either $0.1 \mu \mathrm{M}$ (clones 100,101) or $1 \mu \mathrm{M}$ PPI-2458 (clone 129), or in the absence of PPI-2458 for 7 days. The cells were harvested, seeded at $5 \times 10^{4}$ cells/well (triplicates) and grown in fresh medium in the presence (filled bar) or absence (open bar) of PPI-2458 for another 7 days. The growth medium was collected and the amount of secreted melanin was measured as described in A. (C) Elevated levels of the melanogenic proteins tyrosinase, TRP-1 and TRP-2 induced by PPI-2458. Cellular protein $(30 \mu \mathrm{g})$ from B16F10 cells (clones 100, 101, 129, and G) which had been grown as described in B were analyzed for tyrosinase, TRP-1 and TRP-2, and B-actin expression. 

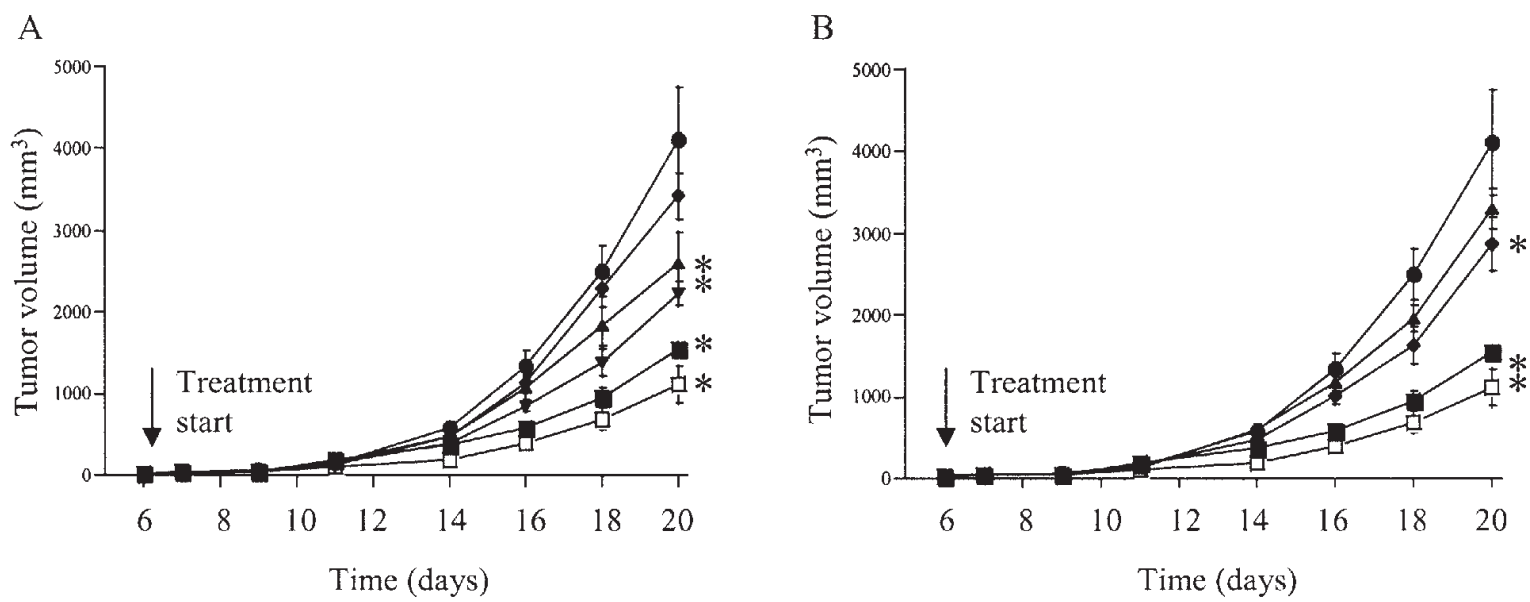

Figure 4. Dose and schedule-dependent B16F10 tumor growth inhibition in C57BL/6 mice after treatment with PPI-2458. (A) 1x10 6 B16F10 (1x107 cells/ml) were injected s.c. above the right hind leg of C57BL/6 mice, and treatment with either vehicle (•), 5-FU (50 mg/kg, i.p. 3x/week) ( $\square$ ), or PPI-2458 [1, 3, 30, $100 \mathrm{mg} / \mathrm{kg}$, p.o., QOD ( $, \mathbf{\Lambda}, \boldsymbol{\nabla}, \boldsymbol{\square}$, respectively)] started 6 days after tumor implantation. Tumor volumes were measured on alternate days until day 20 , starting at day 6 , and calculated using the following equation: volume $=$ (width $\mathrm{x}$ width) (length)/2. (B) Tumors were implanted as described in A, and animals were treated until day 20, starting at day 6 with either vehicle (•), 5-FU (50 mg/kg, i.p., 3x/week) ( $\square$ ), or PPI-2458 (100 mg/kg, p.o., QOD, Q3D, or Q4D) ( $\bullet$, $\Delta$, respectively). Tumor volumes were calculated as described in A. The results represent the mean \pm SEM ( $\mathrm{n}=10$ ), ${ }^{*} \mathrm{p}<0.05$ compared to vehicle-treated animals.

exposed to this agent (Fig. 2). These results suggest that the MetAP-2 pathway(s) that is involved in the regulation of B16F10 cell growth remain sensitive to PPI-2458 inhibition, even after prolonged exposure.

PPI-2458 induces melanogenesis in B16F10 cells. Melanogenesis is functionally associated with differentiated melanocytes (23-25). Prolonged exposure of B16F10 cells to PPI-2458 at concentrations of either 0.1 or $1 \mu \mathrm{M}$ resulted in melanin secretion into the growth medium, with measurable amounts of this pigment first detected after 5 weeks. When B16F10 cells, derived from single clones that had previously been generated from cells grown in the presence of either $0.1 \mu \mathrm{M}$ (clones 100,101$)$ or $1 \mu \mathrm{M}$ (clone 129) of PPI-2458, or that had not been previously exposed to PPI-2458 (clone G), were incubated with increasing conditions of PPI-2458, we observed a dose-dependent increase in secreted melanin (Fig. 3A). The maximum level of melanin secretion occurred at PPI-2458 concentrations of $\geq 10 \mathrm{nM}$, which was consistent with the lowest concentration of PPI-2458 required to achieve maximal growth inhibition in these cells. The total amount of melanin secreted into the growth medium, however, varied significantly between cells from different B16F10 clones (Fig. 3A). We then questioned whether PPI-2458-dependent melanin secretion would be reversible in the absence of this agent. When cells were grown for two weeks in the presence of either $0.1 \mu \mathrm{M}$ PPI-2458 (clones 100, 101) or $1 \mu \mathrm{M}$ PPI-2458 (clone 129), or in the absence of this agent, melanin secretion was completely repressed under the latter condition, supporting the notion of a PPI-2458-dependent mechanism of melanin secretion (Fig. 3B). Melanogenesis is an enzymatic cascade which is regulated by tyrosinase, TRP-1 and TRP-2 $(26,27)$. Tyrosinase is the key enzyme in this process as it controls the first two rate-limiting steps in this cascade, the hydroxylation of tyrosine to 3,4-dihydroxylphenylalanine (DOPA), and its oxidation to dopaquinone. We examined whether the expression levels of these melanogenic proteins were affected by PPI-2458.
Concomitant with the secretion of melanin, we detected significantly elevated levels of tyrosinase, while TRP-1 and TRP-2 protein levels were moderately increased (Fig. 3C). These data suggest that PPI-2458 activates a melanogenic signaling pathway(s) by a molecular mechanism(s) which remains to be elucidated.

PPI-2458 growth inhibition of syngeneic mouse B16F10 tumors. Six days following tumor implantation $\left(1 \times 10^{6} \mathrm{~B} 16 \mathrm{~F} 10\right.$ cells, s.c.), vehicle or PPI-2458 was administered orally to mice at doses of 1,3,30 or $100 \mathrm{mg} / \mathrm{kg}$ QOD, and this treatment regimen was concluded at day 20 . B16F10 melanoma growth was significantly inhibited in a dose-dependent manner at 3 , 30 and $100 \mathrm{mg} / \mathrm{kg}$, with reduction in final tumor volumes of 36 , 46 and $62 \%$, respectively (Fig. 4A). At the dose of $100 \mathrm{mg} / \mathrm{kg}$, the degree of tumor growth inhibition was similar to that observed for 5-FU administered at a maximal tolerated dose (Fig. 4A). The final tumor weights determined at day 20 were closely related to tumor volumes in all treatment groups (Table I). To further investigate the schedule dependence of PPI-2458 on tumor growth inhibition, C57BL/6 mice were treated from 6 days after tumor implantation with $100 \mathrm{mg} / \mathrm{kg}$ PPI-2458, p.o. on QOD, Q3D or Q4D dosing schedules. PPI2458-induced tumor growth inhibition in mice treated on Q3D and Q4D dosing schedules was less effective (30 and 20\%, respectively) when compared to QOD dosing (62\%) (Fig. 4B). These results suggest that QOD dosing is the most efficacious schedule for PPI-2458 in this tumor when administered orally, consistent with the pharmacological half-life of PPI-2458 (data not shown). PPI-2458 was generally well tolerated in all treatment groups, with only minimal weight loss (3\%) observed in the highest dosing group (100 mg/kg, p.o., QOD) (data not shown).

PPI-2458-induced B16F10 melanoma growth inhibition correlates with MetAP-2 enzyme inhibition. To determine whether B16F10 tumor growth inhibition correlates in vivo 
Table I. Decreased tumor weights after treatment with PPI-2458. ${ }^{\mathrm{a}}$

\begin{tabular}{lll}
\hline Agent & Therapeutic regimen & $\begin{array}{c}\text { Tumor weight } \\
(\mathrm{g}) \pm \text { SEM }\end{array}$ \\
\hline Vehicle & $0 \mathrm{mg} / \mathrm{kg}$, p.o., QOD & $3.27 \pm 0.37$ \\
5 -FU & $50 \mathrm{mg} / \mathrm{kg}$, i.p., 3x/week & $1.26 \pm 0.31^{\mathrm{b}}$ \\
PPI-2458 & $1 \mathrm{mg} / \mathrm{kg}$, p.o., QOD & $3.04 \pm 0.25$ \\
PPI-2458 & $3 \mathrm{mg} / \mathrm{kg}$, p.o., QOD & $2.48 \pm 0.38$ \\
PPI-2458 & $30 \mathrm{mg} / \mathrm{kg}$, p.o., QOD & $2.12 \pm 0.15^{\mathrm{b}}$ \\
PPI-2458 & $100 \mathrm{mg} / \mathrm{kg}$, p.o., QOD & $1.53 \pm 0.15^{\mathrm{b}}$ \\
PPI-2458 & $100 \mathrm{mg} / \mathrm{kg}$, p.o., Q3D & $2.39 \pm 0.22^{\mathrm{b}}$ \\
PPI-2458 & $100 \mathrm{mg} / \mathrm{kg}$, p.o., Q4D & $2.65 \pm 0.17$ \\
\hline
\end{tabular}

B16F10 tumors were implanted as described in Materials and methods.

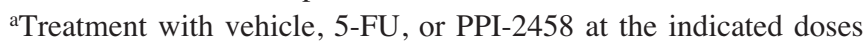
started at day 6 and continued until day 20. The animals were sacrificed and their tumors removed and weighed. The number of mice per group ranged from 7 to 10 , except for the 5-FU group $(\mathrm{n}=5)$. The results represent the mean $\pm \mathrm{SEM} ;{ }^{b} \mathrm{p}<0.05$ compared to vehicle-treated animals.

with the inhibition of MetAP-2 function after treatment with PPI-2458, we measured the levels of uninhibited MetAP-2 in tumor tissue extracts $24 \mathrm{~h}$ after conclusion of the study. In animals orally administered PPI-2458 at 1, 3, 30 and $100 \mathrm{mg} /$ $\mathrm{kg}$, QOD, MetAP-2 was dose-dependently inhibited, with a maximum inhibition of $80 \%$ achieved at the highest dose relative to vehicle group levels $24 \mathrm{~h}$ after the final dose (Fig. 5). These levels of MetAP-2 enzyme inhibition correlated closely $(r=0.98)$ with a decrease in B16F10 tumor weights (Fig. 5). Thus, these data provide further experimental evidence that links MetAP-2 enzyme inhibition to the anti-tumor activity of PPI-2458.

Regulation of MetAP-1, MetAP-2 and p21 $1^{\text {CIP/WAF }}$ protein expression in B16F10 cells in vivo after treatment with PPI-2458. To determine the expression of the cell growth regulatory proteins, MetAP-1, MetAP-2 and $\mathrm{p} 21^{\mathrm{CIP} / \mathrm{WAF}}$, in B16F10 cells in vivo, we performed Western blot analysis on melanoma tumor extracts from mice which had been treated with PPI-2458 (3, 30, and $100 \mathrm{mg} / \mathrm{kg}$, p.o., QOD). While the cellular level of MetAP-1 was not affected by PPI-2458 treatment, MetAP-2 expression was elevated at the highest dose of PPI-2458 used in this study, suggesting induction or stabilization of this protein (Fig. 6). Moreover, p $21^{\mathrm{CIP} / \mathrm{WAF}}$ levels were significantly increased after treatment with 30 and $100 \mathrm{mg} / \mathrm{kg}$ PPI-2458 (Fig. 6). These data suggest that the same PPI-2458-dependent mechanism(s) involved in the regulation of these genes in $\mathrm{B} 16 \mathrm{~F} 10$ cells in vitro also function in vivo. Notably, treatment with $5-\mathrm{FU}(50 \mathrm{mg} / \mathrm{kg}$, i.p. 3x/week) significantly decreased MetAP-2 levels, while p21 CIP/WAF levels increased (Fig. 6), suggesting a potential role for these cell growth regulatory proteins in 5-FU-mediated B16F10 tumor growth inhibition.

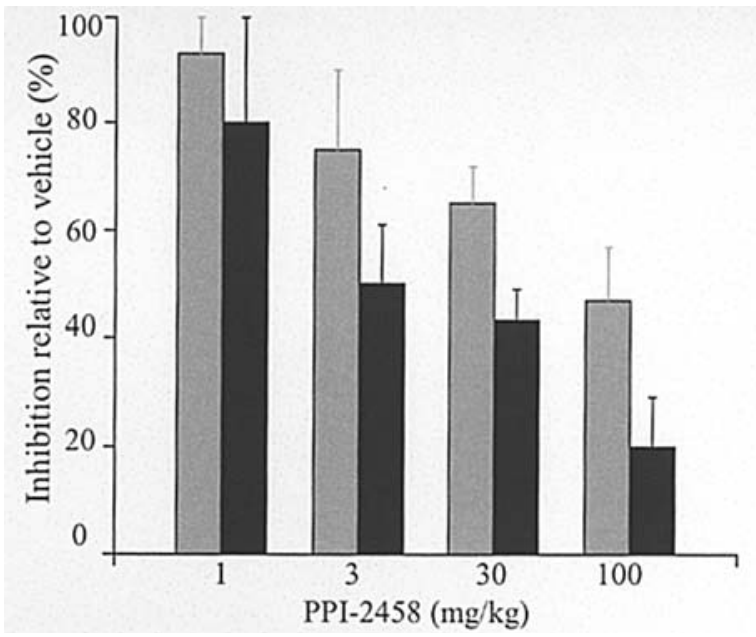

Figure 5. MetAP-2 inhibition correlates with B16F10 tumor growth inhibition after treatment with PPI-2458. Tumors were collected from mice ( $\mathrm{n}=4$ /group) treated with PPI-2458 (1, 3, 30, or $100 \mathrm{mg} / \mathrm{kg}$ PPI-2458, p.o., QOD), $24 \mathrm{~h}$ after the final dose. The amount of uninhibited MetAP-2 in tumor extracts (black bars) was measured as described in Materials and methods. Tumor weights (gray bars) are plotted as listed in Table I. The results represent the mean \pm SEM.

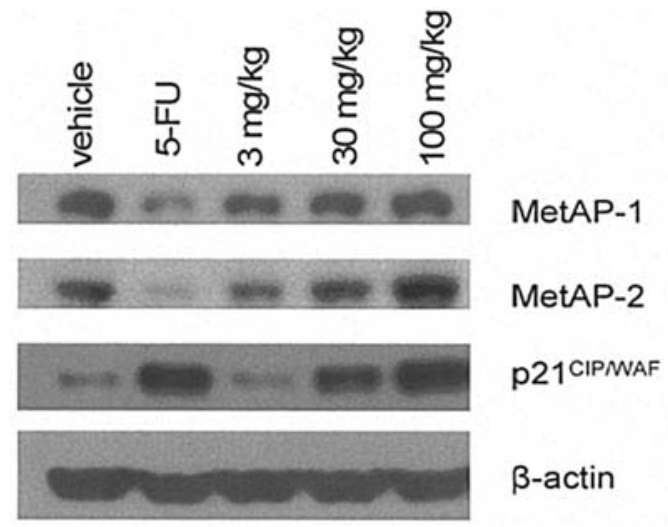

Figure 6. Western blot analysis of MetAP-1, MetAP-2 and p21 ${ }^{\text {CIP/WAF }}$ protein expression in B16F10 tumor tissue after treatment with PPI-2458. Tumor extracts of melanomas derived from $\mathrm{C} 57 \mathrm{BL} / 6$ mice treated with vehicle, 5 -FU (50 mg/kg, i.p., 3x/week) or PPI-2458 (3, 30, and $100 \mathrm{mg} / \mathrm{kg}$, p.o., QOD) were prepared as described in Materials and methods, and $30 \mu \mathrm{g}$ of cellular protein was analyzed for either MetAP-1, MetAP-2, p21 CIP/WAF, or ß-actin expression.

\section{Discussion}

Currently available therapies for patients with advanced, metastatic melanoma have not yet achieved significant clinical benefit in terms of improved survival rates and the prognosis for these patients is generally poor. Novel, innovative therapies for the treatment of this disease are urgently needed, and a number of therapeutic agents are undergoing active clinical investigation (2). In this report, we present data that provide a rationale to investigate the use of PPI-2458 for the treatment of melanoma. PPI-2458 is a novel, orally active analog of fumagillin $(17,28)$. Similar to TNP-470 (AGM-1470), PPI-2458 has potent antiangiogenic properties and inhibits the proliferation of selective tumor cell lines by irreversible inhibition 
of the enzyme, MetAP-2, the molecular target of fumagillin class molecules $(16,17)$.

PPI-2458 potently inhibited the proliferation of B16F10 melanoma cells with a $\mathrm{GI}_{50}$ of $0.2 \mathrm{nM}$. The functional significance of MetAP-2 inhibition on B16F10 cell growth was investigated by measuring the amount of uninhibited MetAP-2 enzyme in these cells after exposure to PPI-2458, using a pharmacodynamic assay $(16,17)$. Although the growth of B16F10 cells was not completely inhibited, even at the highest concentration of PPI-2458, both complete MetAP-2 enzyme inhibition and maximal growth inhibition was achieved at $\geq 10 \mathrm{nM}$. This dose-dependent correlation between B16F10 cell growth inhibition and MetAP-2 enzyme inhibition supports the notion of a critical function of MetAP-2 in growth control of sensitive B16F10 cells. These results are further consistent with previous studies which report a critical role for MetAP-2 as a molecular regulator of cell growth, and suggested that MetAP-2 inhibition is an important component in the control of proliferation in cells sensitive to PPI-2458 growth inhibition $(16,17)$. The relative level of cellular MetAP-2 protein, however, did not affect the growth inhibitory activity of PPI-2458. While MetAP-2 protein levels in these cells were moderately increased after treatment with PPI-2458, similar increases have been reported for other cell types, most likely due to increased protein stability and elevated transcription of MetAP-2 $(16,17,29,30)$. In contrast to MetAP-2, the expression of MetAP-1 (16,31), an enzyme related to MetAP-2 with cell-type specific functional redundancy in cell growth control, was not affected by the exposure of B16F10 cells to PPI-2458.

We also report that PPI-2458 treatment resulted in elevated levels of $\mathrm{p} 21^{\mathrm{CIP} / \mathrm{WAF}}$ in B16F10 cells. In HUVEC, the molecular mechanism of the $G_{1}$ cell cycle arrest induced by fumagillin class molecules is most likely triggered by activation of the p53 signaling pathway and intracellular accumulation of the cell cycle inhibitor protein, p21 $1^{\mathrm{CIP} / \mathrm{WAF}}(20,21)$. Genomic studies of several cell cycle regulatory genes in B16F10 cells have provided no evidence of mutations in the p53 gene, although p53 protein levels are relatively low, due to the inactivation of the p19ARF gene in these cells (22). Hence, we reasoned that the p53 signaling pathway could be functional, and that the accumulation of $\mathrm{p} 21^{\mathrm{CIP} / \mathrm{WAF}}$ following treatment of B16F10 cells with PPI-2458 would suggest a conserved mechanism of $\mathrm{p} 53 / \mathrm{p} 21^{\mathrm{CIP} / \mathrm{WAF}}$-induced growth inhibition, similar to HUVEC. The detection of elevated levels of $\mathrm{p} 21^{\mathrm{CIP} / \mathrm{WAF}}$ protein at PPI-2458 concentrations which induced maximal growth inhibition is consistent with the notion of a growth regulatory function of $\mathrm{p} 21^{\mathrm{CIP} / \mathrm{WAF}}$ in B16F10 cells. In $\sim 65-70 \%$ of all human melanomas, mutations in the $B R A F$ oncogene result in activation of the MEK/ERK proliferation pathway, in a $R A S$-dependent or -independent fashion (32-37). In contrast, no $B R A F$ mutations and, consequently, no activation of the $R A S$ pathway have been found in $\mathrm{B} 16 \mathrm{~F} 10$ or other mouse melanoma cell lines (22). Due to the unique molecular mechanism of PPI-2458, these observations suggest a potentially important role for this agent in the treatment of melanoma, either in combination with chemotherapeutic drugs or with novel agents designed to target yet unexplored signaling pathways in melanoma, such as the BRAF kinase inhibitor, BAY 43-9006 $(38,39)$. One hallmark of advanced metastatic melanomas is resistance to currently available therapeutic regimens, due to the ability to evade the cytotoxic activity of conventional chemotherapeutic drugs and to escape the surveillance mechanisms of the immune system. In contrast, we were unable to generate B16F10 cells resistant to PPI-2458 growth inhibition even after prolonged exposure to PPI-2458 at concentrations of up to $1 \mu \mathrm{M}\left(\sim 5,000\right.$-fold above the $\left.\mathrm{GI}_{50}\right)$. Moreover, the degree of sensitivity to PPI-2458 growth inhibition remained unchanged from that of cells not previously exposed to this agent, consistent with previously reported findings that PPI-2458 growth inhibition is reversible, and further supporting the notion that the activity of this agent is exerted by a mechanism of cytostasis (17).

In addition to persistent drug sensitivity, prolonged exposure of B16F10 cells to PPI-2458 resulted in melanogenesis concomitant with an increase in cellular levels of the melanocyte-specific proteins tyrosinase, TRP-1 and TRP-2. This increase was most prominent for tyrosinase, the key enzyme in the melanogenesis cascade, which provides a potential molecular mechanism for the observed PPI-2458dependent melanin synthesis and secretion. Similar to PPI2458 growth inhibition, the induction of melanogenesis by PPI-2458 was reversible. Physiologically, this process is regulated by ultra-violet $\mathrm{A}$ and $\mathrm{B}$ radiation and by a large array of effectors including $\alpha$-melanocyte stimulating hormone $(\alpha-\mathrm{MSH})(40,41)$. Several pharmacological agents which mimic the cyclic-AMP elevating activity of $\alpha-\mathrm{MSH}$, such as forskolin and cholera toxin, and chloroethylnitrosoureas, which alter the phospholipid metabolism of affected cells, have also been shown to induce melanogenesis (42-45). These results suggest that multiple signaling pathways can independently activate the complex network of transcription factors which positively and negatively regulate this process and that PPI-2458 may promote terminal differentiation of the malignant cellular phenotype.

Tyrosinase, TRP-1, TRP-2 are among a group of melanocyte-specific proteins that have been identified as potential targets for tumor-directed immunotherapy for melanoma (8-12). Although these self-antigens have the potential to support the generation of a host immune response against normal and transformed melanocytes, expression alone is usually insufficient to provide protection against tumor growth. Nevertheless, the increase in tyrosinase, TRP-1 and TRP-2 protein expression induced by PPI-2458, suggests that this drug could potentially support the generation of a tumor-directed immune response.

The mouse syngeneic B16F10 tumor is a well-established model for solid tumor formation and metastasis. PPI-2458, when orally administered, significantly inhibited the growth of this tumor in a dose-dependent fashion, with a maximum inhibition of $62 \%$ at $100 \mathrm{mg} / \mathrm{kg}$. Similar results were observed after oral treatment with PPI-2458 in the human UACC-62 melanoma xenograft and several other solid tumors in mice, further supporting the notion of PPI-2458 as an orally active MetAP-2 inhibitor with potent anti-tumor activity (Hollingshead et al: AACR/NCI/EORTC Int Conf Mol Targets Cancer Ther, abs. C41, 2003). Investigations of the anti-tumor activity of TNP-470 in the B16F10 mouse melanoma model have previously shown growth inhibitory activity of this agent after s.c. and i.v. administration, while oral administration was reported as the least efficacious route (46). Moreover, 
despite some initially promising results of this drug in clinical trials, the clinical development of TNP-470 was halted, in part, due to difficulties with optimizing the dosing regimen dependent on intravenous infusion, combined with the short circulating half-life of this agent (47-49). B16F10 tumor growth inhibition by PPI-2458, when orally administered, was accompanied by a decrease of uninhibited MetAP-2 in tumor tissue $(80 \%$ at $100 \mathrm{mg} / \mathrm{kg}$ ), strongly supporting a correlation between tumor growth inhibition and the inhibition of MetAP-2 in this model. Despite the correlation between tumor growth inhibition and MetAP-2 enzyme inhibition in tumor tissue, we cannot exclude the possibility that the antitumor activity of PPI-2458 was, at least in part, due to the antiangiogenic properties of this molecule $(16,17)$. In addition to the direct anti-tumor activity of PPI-2458, antiangiogenesis could provide additional benefit in vivo in combination with other chemotherapeutic drugs. Moreover, further clinical benefit could arise from a potential effect of PPI-2458 on terminal differentiation of melanoma cells, as suggested by the observed melanogenesis. The established antagonism between cell growth and differentiation is well established, and agents that induce cell differentiation, such as 13-cis retinoic acid, have entered clinical trials (50).

In conclusion, the data presented here demonstrate that PPI-2458 potently inhibited the growth of B16F10 melanoma cells in vitro and in vivo, and that this growth inhibition directly correlated with the inhibition of the molecular target of this molecule, MetAP-2. These results provide a rationale for assessing the therapeutic potential of PPI-2458 as a novel, molecularly targeted therapy for the treatment of melanoma.

\section{References}

1. Chudnovsky Y, Khavari PA and Adams AE: Melanoma genetics and the development of rational therapeutics. J Clin Invest 115: 813-824, 2005.

2. Tarhini AA and Agarwala SS: Novel agents in development for the treatment of melanoma. Expert Opin Invest Drugs 14: 885-892, 2005.

3. Eggermont AM and Kirkwood JM: Reevaluating the role of dacarbazine in metastatic melanoma: what have we learned in 30 years? Eur J Cancer 40: 1825-1836, 2004

4. Serrone L, Zeuli M, Sega FM and Cognetti F: Dacarbazinebased chemotherapy for metastatic melanoma: thirty year experience overview. J Exp Clin Cancer Res 19: 21-34, 2000.

5. Agarwala S: Improving survival in patients with high-risk and metastatic melanoma: immunotherapy leads the way. Am J Clin Dermatol 4: 333-346, 2003.

6. Nestle M and Carol H: Melanoma. In: Dermatology. Bolognia J, Jorizzo J and Rapini R (eds). Mosby, New York, pp1789-1815, 2003.

7. Margolin KA: Biochemotherapy for melanoma: rational therapeutics in the search for weapons of melanoma destruction. Cancer 101: 435-438, 2004.

8. Bellone M, Cantarella D, Castiglioni P, et al: Relevance of the tumor antigen in the validation of three vaccination strategies for melanoma. J Immunol 165: 2651-2656, 2000.

9. Bronte V, Apolloni E, Ronca R, et al: Genetic vaccination with 'self' tyrosinase-related protein 2 causes melanoma eradication but not vitiligo. Cancer Res 60: 253-258, 2000.

10. Chen Y-T, Stockert E, Tsang S, Coplan KA and Old LJ: Immunophenotyping of melanomas for tyrosinase: implications for vaccine development. Proc Natl Acad Sci USA 92: 8125- 8129, 1995.

11. Mitchell MS, Darrah D, Yeung D, et al: Phase I trial of adoptive immunotherapy with cytolytic T lymphocytes immunized against a tyrosinase epitope. J Clin Oncol 20: 1075-1086, 2002.

12. Sakai C, Kawakami Y, Law LW, Furumura M and Hearing VJ Jr: Melanosomal proteins as melanoma-specific immune targets. Melanoma Res 7: 83-95, 1997.
13. Griffith EC, Su Z, Turk BE, et al: Methionine aminopeptidase (type 2) is the common target for angiogenesis inhibitors AGM-1470 and ovalicin. Chem Biol 4: 461-467, 1997.

14. Sin N, Meng L, Wang MQW, Wen JJ, Bornmann WG and Crews CM: The anti-angiogenic agent fumagillin binds and inhibits the methionine aminopeptidase, MetAP-2. Proc Natl Acad Sci USA 94: 6099-6103, 1997.

15. Liu S, Widom J, Kemp CW, Crews CM and Clardy J: Structure of human methionine aminopeptidase-2 complexed with fumagillin. Science 282: 1324-1327, 1998.

16. Bernier SG, Taghizadeh N, Thompson CD, Westlin WF and Hannig G: Methionine aminopeptidases type I and type II are essential to control cell proliferation. J Cell Biochem 95: 1191-1203, 2005.

17. Bernier SG, Lazarus DL, Clark E, Doyle B, Labenski MT, Thompson CD, Westlin WF and Hannig G: A methionine aminopeptidase-2 inhibitor, PPI-2458, for the treatment of rheumatoid arthritis. Proc Natl Acad Sci USA 101: 10768-10773, 2004.

18. Gruber JR, Ohno S and Niles RM: Increased expression of protein kinase $\mathrm{C} \alpha$ plays a key role in retinoic acid-induced melanoma differentiation. J Biol Chem 267: 13356-13360, 1992.

19. Turk B, Griffith EC, Wolf S, Biemann K, Chang YH and Liu JO: Selective inhibition of amino-terminal methionine processing by TNP-470 and ovalicin in endothelial cells. Chem Biol 4: 823-833, 1999.

20. Yeh J-JJ, Mohan R and Crews CM: The antiangiogenic agent TNP-470 requires $\mathrm{p} 53$ and $\mathrm{p} 21^{\mathrm{CIP} / \mathrm{WAF}}$ for endothelial cell growth arrest. Proc Natl Acad Sci USA 97: 12782-12787, 2000.

21. Zhang Y, Griffith, EC, Sage J, Jacks T and Liu JO: Cell cycle inhibition by the anti-angiogenic compound TNP-470 is mediated by $\mathrm{p} 53$ and p21 CIP/WAF. Proc Natl Acad Sci USA 97: 6427-6432, 2000 .

22. Melnikova VO, Bolshakov SV, Walker C and Ananthaswamy HN: Genomic alterations in spontaneous and carcinogen-induced murine melanoma cell lines. Oncogene 23: 2347-2356, 2004.

23. Busca R, Bertoletto C, Ortonne J-P and Balotti R: Inhibition of the phosphatidylinositol 3-kinase/p70 $0^{\mathrm{S} 6}$-kinase pathway induces B16 melanoma cell differentiation. J Biol Chem 271: 31824-31830, 1996.

24. Gaggioli C, Busca R, Abbe P, Ortonne J-P and Balotti R: Microphthalmia-associated transcription factor (MITF) is required but not sufficient to induce expression of melanogenic genes. Pigment Cell Res 16: 374-382, 2003.

25. Haddad MM, Xu W, Schwahn D, Liao F and Medrano EE: Activation of a cAMP pathway and induction of melanogenesis correlate with association of $\mathrm{p} 16^{\mathrm{INK} 4}$ and $\mathrm{p} 27^{\mathrm{KIP} 1}$ to CDKs, loss of E2F-binding activity, and premature senescence of human melanocytes. Exp Cell Res 253: 561-572, 1999.

26. Hearing VJ and Jimenez M: Mammalian tyrosinase - the critical regulatory control point in melanocyte pigmentation. Int J Biochem 19: 1141-1147, 1987 .

27. Hearing VJ and Jimenez M: Analysis of mammalian pigmentation at the molecular level. Pigment Cell Res 2: 75-85, 1989.

28. Bernier SG, Westlin WF and Hannig G: Fumagillin class inhibitors of methionine aminopeptidase-2. Drugs Future 30: 497-508, 2005.

29. Wang J, Lou P and Henkin J: Selective inhibition of endothelial cell proliferation by fumagillin is not due to differential expression of methionine aminopeptidases. J Cell Biochem 77: 465-473, 2000.

30. Datta B, Mjumdar A, Datta R and Balusu R: Treatment of cells with the angiogenic inhibitor fumagillin results in increased stability of eukaryotic initiation factor-2 associated glycoprotein, p67, and reduced phosphorylation of extracellular signal-regulated kinases. Biochemistry 43: 14821-14831, 2004.

31. Nagase T, Miyajima N, Tanaka A, Sazuka T, et al: Prediction of the coding sequences of unidentified human genes. III. The coding sequences of 40 new genes (KIAA0081-KIAA0120) deduced by analysis of cDNA clones from human cell line KG-1. DNA Res 2: 37-43, 1995.

32. Davies H, Bignell GR, Cox C, et al: Mutations of the BRAF gene in human cancer. Nature 417: 949-954, 2002.

33. Calipel A, Lefevre G, Pouponnot C, Mouriaux F, Eychene A and Mascarelli F: Mutation of B-Raf in human choroidal melanoma cells mediates cell proliferation and transformation through the MEK/ERK pathway. J Biol Chem 278: 42409-42418, 2003.

34. Goydos JS, Mann B, Kim HJ, et al: Detection of B-RAF and N-RAS mutations in human melanoma. J Am Coll Surg 200: 362-370, 2005. 
35. Hingorani SR, Jacobetz MA, Robertson GP, Herlyn M and Tuveson D: Suppression of BRAF (V599E) in human melanoma abrogates transformation. Cancer Res 63: 5198-5202, 2003.

36. Karasarides M, Chiloeches A, Hayward R, et al: B-RAF is a therapeutic target in melanoma. Oncogene 23: 6292-6298, 2004

37. Wellbrock C, Ogilvie L, Hedley D, et al: V599EB-RAF is an oncogene in melanocytes. Cancer Res 64: 2338-2342, 2005.

38. Ahmad T and Eisen T: Kinase inhibition with BAY 43-9006 in renal carcinoma. Clin Cancer Res 10: S6388-S6392, 2004.

39. Lyons JF, Wilhelm S, Hibner B and Bollag G: Discovery of a novel Raf kinase inhibitor. Endocr Relat Cancer 8: 219-225, 2001.

40. Hearing VJ and Tsukamoto K: Enzymatic control of pigmentation in mammals. FASEB J 5: 2902-2909, 1991.

41. Levine N, Sheftel SN, Eytan T, et al: Induction of skin tanning by subcutaneous administration of a potent synthetic melanotropin. JAMA 266: 2730-2736, 1991

42. Englaro W, Rezzonico R, Durand-Clement M, Lallemand D, Ortonne JP and Balotti R: Mitogen-activated protein kinase pathway and AP-1 are activated during cAMP-induced melanogenesis in B-16 melanoma cells. J Biol Chem 270: 24315-24320, 1995.

43. Hunt G, Todd C, Cresswell JE and Thody AJ: Alpha-melanocyte stimulating hormone and its analogue Nle4DPhe7 alpha-MSH affect morphology, tyrosinase activity and melanogenesis in cultured human melanocytes. J Cell Sci 107: 205-211, 1994.

44. Morvan D, Demidem A, Papon J, De Latour M and Madelmont JC: Melanoma tumors acquire a new phospholipids metabolism phenotype under cystemustine as revealed by highresolution magic angle spinning proton nuclear magnetic resonance spectroscopy of intact tumor samples. Cancer Res 62: $1890-1897,2002$
45. Demidem A, Morvan D, Papon J, De Latour M and Madelmont JC: Cystemustine induces redifferentiation of primary tumors and confers protection against secondary tumor growth in a melanoma murine model. Cancer Res 61: 2294-2300, 2001.

46. Yamaoka M, Yamamoto T, Masaki T, Ikeyama S, Sudo K and Fujita T: Inhibition of tumor growth and metastasis of rodent tumors by the angiogenesis inhibitor O-(chloroacetylarbamoyl)fumagillol (TNP-470; AGM-1470). Cancer Res 53: 4262-4267, 1993.

47. Figg WD, Pluda JM, Lush RM, Saville MW, Wyvill K, Reed E and Yarchoan R: The pharmacokinetic profile of TNP-470, a new angiogenesis inhibitor. Pharmacotherapy 17: 91-97, 1997.

48. Bhargava P, Marshall JL, Rizvi N, et al: A phase I and pharmacokinetic study of TNP-470 administered weekly to patients with advanced cancer. Clin Cancer Res 5: 1989-1995, 1999.

49. Moore JD, Dezube BJ, Gill P, Zhou X-J, Acosta EP and Sommadossi J-P: Phase I dose escalation pharmacokinetics of O-(chloroacetylcarbamoyl) fumagillol (TNP-470) and its metabolites in AIDS patients with Kaposi's sarcoma. Cancer Chemother Pharmacol 46: 173-179, 2000.

50. Recchia F, De Filippis S, Rosselli M, Saggio G, Cesta A, Fumagalli L and Rea S: Phase 1B study of subcutaneously administered interleukin 2 in combination with 13-cis retinoic acid as maintenance therapy in advanced cancer. Clin Cancer Res 7: 1251-1257, 2001. 